\title{
PERAN GURU KELAS DALAM PEMBENTUKAN KARAKTER MELALUI PEMBELAJARAN TEMATIK DI SEKOLAH DASAR \\ Oleh
}

\author{
Sy. Rohana \\ Dosen Pendidikan Agama Islam, STAIN Teungu Dirundeng Meulaboh \\ E-mail: Sy.rohana@staindirundeng.ac.id
}

\begin{abstract}
Abstrak
Pembahasan ini bertujuan untuk mengkaji peran guru kelas dalam pembentukan karakter dengan proses pembelajaran tematik. Metode yang digunakan dalam pembahasan ini adalah metode penelitian perpustakaan. Perpustakaan salah satu sumber rujukan dalam pembahasan ini dengan menelaah dari berbagai sumber dari buku-buku, majalah, jurnal, dan lainnya sesuai dengan topik dari pembahasan serta relevan. Hasil dari pembahasan menggambarkan bahwa peran guru kelas dalam pembentukan karakter melalui pembelajaran tematik di sekolah dasar harus dilaksanakan dengan menerapkan disemua mata pelajaran tentang pendidikan karakter melalui ketedalanan dan pembiasaan terutama gurunya sendiri. Salah satu cara adalah guru dalam merencanakan pembelajaran tematik untuk menanamkan nilai karakter yaitu dengan membuat RPP serta menyelipkan tentang nilai karakter, menyiapkan media, metode, bahan ajar serta lembaran penilaian. Sebagai bahan pendukung setiap hari jum'at ada kegiatan rutin ceramah 15 menit guru di kelas.
\end{abstract}

Kata Kunci: Peran Guru Kelas, Pembentukan Karakter, Pembelajaran Tematik.

\section{Abstract}

This paper aims to examine the role of class teachers in character formation through a thematic learning process. The method used in this discussion is the library research. The library is one of the sources of reference in this discussion by examining various sources from books, magazines, journals, and others for the topics of the relevant discussion. The results of the discussion make it clear that the role of the class teacher in character formation through thematic learning in elementary schools must be implemented through the implementation of character education in all subjects. Namely through exemplary and habituation exemplified by the teacher himself. Promoting character values through thematic learning includes, among other things, inserting character values into the lesson plans and preparing media, methods, teaching materials and assessment sheets.. As supporting material, there are routine activities in the form of 15-minute lectures by the teacher in class every Friday.

Keywords: Role of the Class Teacher, Character Building, Thematic Learning 


\section{PENDAHULUAN}

Guru adalah seorang yang berperan dalam pendidikan yng sekaligus penentu berhasil tidaknya suatu proses pembelajaran. Peran guru dalam dunia pendidikan modern semakin kompleks, tidak hanya sekedar sebagai pengajar akan tetapi juga sebagai pendidik karakter, moral dan budaya. Dengan demikian pendidikan karakter sangat penting untuk dipahami dan diterapkan di sekolah. Sekolah adalah wahana pengembangan Pendidikan karakter bagi anak didik. Guru sebagai pendidik mempunyai tanggung jawab besar dalam mencetak generasi yang berkarakter, bermoral dan berbudaya. Guru juga teladan bagi anak didik mempunya peran yang sangat besar dalam pembentukan karakter anak didik.

Ramayulis dalam Ilmu Pendidikan Islam. Jakarta: Kalam Media,2008, h, 13 mengutip dari Undang-Undang Pendidikan" Dalam Undang-Undang Sistem Pendidikan Nasional tahun 2003 tentang Sistem Pendidikan Nasional dinyatakan bahwa pendidikan adalah usaha sadar dan terencana untuk mewujudkan suasana belajar dan proses pendidikan pembelajaran agar peserta didik secara aktif mengembangkan potensi dirinya untuk memiliki kekuatan spiritual keagamaan, pengendalian diri, kepribadian, kecerdasan, akhlak mulia, serta keterampilan yang diperlukan dirinya, masyarakat, bangsa dan negara"

Sekolah Dasar atau Madrasah Ibtidaiyah adalah Lembaga Pendidikan dasar yang rentang usia anak didiknya 6-13 tahun, usia yang selalu ingin tahu dan membutuhkan pembimbing yang dapat ia jadikan idolanya. Guru kelas memiliki peran yang sangat menentukan dalam pembentukan kepribadian atau karakter siswa. Sebab, guru kelas merupakan salah satu idola bagi dirinya. Oleh karena itu, guru kelas harus memiliki kepribadian yang mantap atau berkarakter yang kuat sehingga bisa menjadi teladan bagi siswa nya. Dalam pembentukan karakter anak didik dibantu oleh guru lainnya agar lebih kuat dalam menopang penanaman karakter dan jati diri pada anak sehingga menghasilkan peserta didik yang memiliki kepribadian unggul dan berakhlak mulia. Pendidikan karakter akan melahirkan pribadi unggul yang tidak hanya memiliki kemampuan kognitif saja namun memiliki karakter yang mampu mewujudkan kesuksesan. Guru memiliki peranan yang sangat penting dalam menentukan keberhasilan pendidikan. Pendidikan karakter bertujuan untuk meningkatkan mutu proses dan hasil pendidikan yang mengarah pada pembentukan karakter dan akhlak mulia peserta didik secara utuh, terpadu, dan seimbang, sesuai dengan standar kompetensi lulusan pada tiap satuan pendidikan. Menurut kementerian pendidikan nasional pendidikan karakter bertujuan mengembangkan nilainilai yang membentuk karakter bangsa yaitu Pancasila, meliputi: a) mengembangkan potensi peserta didik agar menjadi manusia berhati baik berfikiran baik, dan berperilaku baik, b) membangun bangsa yang berkarakter pancasila, c) mengembangkan potensi warga Negara agar memiliki sikap percaya diri, bangga pada bangsa dan negaranya serta mencintai umat manusia

Menurut Dewantara (2013: 408) karakter adalah imbangan yang tetap antara hidup dan batinnya seseorang dengan segala macam perbuatannya. Oleh karena itu seolah-olah menjadi sendi dalam hidupnya lalu mewujudkan sifat perangai khusus buat satu-satunya manusia. Menurut Wahyudi (2012: 42) karakter merupakan ciri khas seseorang atau sekelompok orang yang mengandung nilai, kemampuan, kapasitas moral, dan ketegaran dalam menghadapi kesulitan dan tantangan. Dari beberapa cara guru dalam membentuk karakter siswa maka ada tujuan dari pendidikan karakter. Menurut Kementerian Pendidikan Nasional (Kemendiknas, 2010: 7) tujuan pendidikan karakter adalah mendorong lahirnya anak-anak yang baik.

Jadi penanaman nilai-nilai karakter sangat perlu pengembangannya sejak dini, karena dewasa ini sangat banyak antar anak didik saling tawuran, dan banyak terjadi kekerasan. Maka 
dalam rangka meningkatkan nilai karakter dan mutu pendidikan terhadap anak didik yang memiliki sikap kurang etis, misalnya belum mengerti dengan sikap bersahabat ataupun tanggung jawab dan ini juga sering terjadi pada anak didik di sekolah dasar, maka salah satu caranya adalah melalui pendidikan di setetiap mata pelajaran harus diselipkan dalam RPP tentang pendidikan karakter, dengan demikian setiap anak didik sudah ada pendidikan dasar tentang pendidikan karakter, paling tidak bisa meminimalisir sifat-sifat yang tidak baik sejak dini.

\section{A. Metode Pembahasan}

Dalam menulis sebuah tulisan tentunya harus ada pedoman penulisan yang sesuai dengan judul dari tulisan yang hendak ditulis. Tulisan ini menggunakan analis dari buku, maka akan menggunakan metode Pustaka, karena Pustaka salah satu tempat literatur umum, baik dalam bentuk buku, jurnal, majalah, dukumen, dan dalam bentuk lainnya.

Sutrisno Hadi (1990) menjelaskan penelitian kepustakaan karena data dan bahan yang diperlukan dalam menyelesaikan sebjuah penenilitian dan pembahasan bersumber dari Pustaka baik berupa buku, ensiklopedia, kamus, jurnal, dukumen, majalah, dan lainnya. Menurut Sumadi Surya Brata (1995) paling tidak ada dua kriteria yang biasa digunakan untuk memilih sumber bacaan yaitu; a) prinsip kemutakhiran (recency) dan b) prinsip relevansi (relevance). Dalam pembahasan ini penulis menggunakan kedua kriteria tersebut untuk menghasilkan tulisan yang baik.

\section{PEMBAHASAN}

\section{Pengertian Guru Sekolah Dasar}

Moh. Roqib dan Nurfuadi (2009:22) "guru adalah seorang yang memiliki tugas untuk mencerdaskan bangsa dalam berbagai aspek kehidupan baik aspek spiritual, emosional, intelektual, fisik, fianansial, dan aspek-aspek lainnya dengan mengembangkan kemampuan anak didik melalui ranah kognitif, afektif dan psikomotor. Dengan demikian guru tidak hanya mengembangkan kemampuan pengetahuan akan tetapi juga mengembangkan kemapuan anak didik dalam bersikap dan melakukan, sihingga anak didik akan memiliki kepribadian yang cakap untuk mengimplementasikan semua pengetahuan secara baik dan optimal.

Berdasarkan pendapat diatas dapat disimpulkan bahwa guru sekolah dasar adalah sosok yang melakukan kegiatan mengajar dan mendidik dalam dunia pendidikan khususnya pada tingkat pendidikan dasar. Melalui guru sekolah dasar akan tercipta bangsa yang kuat dan hebat, karena pada dasarnya pengembangan pendidikan peserta didik untuk tingkat selanjutnya terletak pada pendidikan dasar yang dialaminya. Guru tidak hanya memiliki tugas sebatas mengajar saja, tetapi guru sekolah dasar juga dituntut untuk mampu mengembangkan segala aspek yang mencerdaskan kehidupan bangsa di kehidupan mendatang. Tugas dan tanggung jawab utama guru disekolah adalah melaksanakan proses pembelajaran, disamping tugas-tugas yang lain.

\section{Peran Guru Sekolah Dasar}

Peran merupakan sesuatu kegiatan yang dilakukan sesorang dalam suatu masyarakat. Masyarakat pada konteks ini adalah masyarakat sekolah dasar. Dengan demikian peran guru sekolah dasar adalah sesuatu kegiatan yang dilakukan oleh guru dalam proses pembelajaran yang tidak bisa digantikan oleh siapapun. 
Moh Roqib dan Nurfuadi 2009 ;107) Dalam dunia pendidikan guru tidak hanya memiliki tanggung jawab sebagai dan tugas sebagai pendidik, tetapi guru juga memiliki peran yang harus dilaksanakan dalam proses belajar- mengajar di sekolah. Moh Roqib dan Nurfuadi (2009 : 10-11) menyatakan bahwa peranan guru adalah sebagai (1) korektor, (2) inspirator, (3) informator, (4) organistator, (5) motivator, (6) inisiator, (7) fasilitator, (8) pembimbing, (9) demonstator, (10) pengelola kelas, (11) mediator, (12) supervisor, dan (13) evaluator.

Guru merupakan figur yang dianggap serba bisa dalam segala hal. Tidak hanya menjalankan tugasnya, tetapi guru juga memiliki peranan dalam membimbing peserta didik. Tugas dan peranan guru sangat penting dalam pembentukan sifat, sikap dan perilaku dan karakter anak didiknya karena pada dasarnya guru melaksanakan tugasnya selalu berpegang teguh pada prinsip "ing ngarso sung tulodho, ing madya mangun karsa, tut wuri handayani " yang artinya di depan memberi contoh, di tengah memberi semangat dan di belakang memberi dorongan dan arahan".

Dalam masa perkembangannya, peserta didik akan memiliki banyak masalah dan kesulitan-kesulitan yang akan ditemuinya dalam proses pengembangan dirinya. Disinilah peran dan tugas guru sekolah dasar untuk membantu segala kesulitan atau masalah yang dialami peserta didik. Peserta didik adalah individu yang memiliki potensi sangat besar, sehingga tugas guru adalah mengoptimalkan potensi tersebut dengan mejalankan peranya sebagai pemberi bantuan kepada peserta didik.

\section{Pengertian Karakter}

Marzuki mengutip pendapat dari Lickona, dalam bukunya Pendidikan Karakter Islam (Jakarta: Amzah, 2017), h. 21, Karater adalah watak dasar untuk merespon situasi dalam suatu cara yang baik dan bermoral, karakter tersusun kedalam tiga bagian yang saling terkait, diantaranya pengetahuan tentang moral, perasaan bermoral dan prilaku bermoral.

Yenni Fitra Surya dalam Jurnal Obsesi, Vol. 1 No. 1 (2017), h. 55, menjelaskan bahwa karakter adalah cara berpikir dan berprilaku yang menjadi ciri khas tiap individu untuk hidup dan bekerjasama, baik didalam keluarga, masyarakat, bangsa dan negara. Individu yang berkarakter baik adalah individu yang bisa membuat keputusan dan siap untuk mempertanggung jawabkan setiap akibat dari sebuah keputusan yang ia buat.

Selanjutnya Yunus Abidin, mengutip dari Livo dalam bukunya Revitalisasi Penilaian Pembelajaran dalam Konteks Pendidikan Multiliterasi Abad Ke-21, h. 106, menyatakan bahwa karakter adalah keseluruhan tabiat, kualitas yang baik. Lanjutnya karakter juga sering merujuk kepada moral, etika, dan nilai-nilai. Lalu karakter juga dapat dikatakan sebagai kualitas pembeda yang dimiliki seseorang yang mampu menunjukkan siapa orang itu sesungguhnya. Menurutnya karakter lebih mendalam daripada repotasi dan lebih melembaga dibandingkan istilah tempramen, karakter yang lebih dapat dikembangkan untuk memodifikasi perilaku, mendfayagunakan sikap dan ketidak berpihakan.

Dari paparan diatas bahwa, karakter diartikan sebagai akhlak, budi pekerti, moral, tabiat, perilaku seseorang yang menjadi ciri khas serta membedakan antara satu dengan yang lainnya, karakter seseorang tercermin dari kebaikan dan juga perilaku yang ada pada dirinya. Seseorang dikatakan berkarakter baik apabila orang tersebut dapat membuat serta mempertanggungjawabkan segala keputusan yang telah diambil.

\section{Pendidikan Karakter}

Pendidikan karakter harus dibentuk mulai dari dalam memilih pasangan hidup, kemudian kedua orang tua akan menerapkan pendidikan karakter sejak dalam kandungan dan seterusnya. Yang selanjutnya anak akan memasuki masa sekolah, di sekolah anak didik akan 
berhadapan dengan sesama teman dan gurunya. Di sekolah peran guru yang sangat dominan terhadap pembentukan karakter anak didiknya.

Zubaedi, dalam buku Desain Pendidikan Karakter Konsep dan Aplikasinya dalam Lembanga Pendidikan (2015), h.19 “ Pendidikan karakter merupakan usaha yang sungguhsungguh untuk memahami, membentuk, memupuk nilai-nilai etika, baik itu untuk diri sendiri maupun untuk semua kita sebagai warga masyarakat atau sebagai warga negara secara keseluruhan"

Pada dasarnya pendidikan karakter dapat artikan adalah sebagai pendidikan moral, budi pekerti dan juga pendidikan watak yang kesemuanya itu untuk membentuk dan mengembangkan kemampuan anak didik untuk dapat menentukan mana yang baik dan mana yang tidak baik, yang pada akhirnya anak didik bisa menerapkan norma-norma nilai karakter yang sesuai dengan norma yang berlaku dalam kehidupan sehari-hari.

\section{Tujuan Pendidikan Karakter.}

Pendidikan karakter sesuai dengan pasal 3 Undang-Undang Sistem Pendidikan Nasional Nomor 20 Tahun 2003 dalam Bab 2 pasal 3, bahwa "Pendidikan Nasional berfungsi mengembangkan dan membentuk watak serta peradaban bangsa yang bermartabat dalam rangka mencerdaskan kehidupan bangsa, bertujuan untuk berkembangnya potensi anak didik agar menjadi manusia yang beriman dan bertaqwa kepada Tuhan Yang Maha Esa, berakhlak mulia, sehat, berilmu, cakap, kreatif, mandiri dan menjadi warga negara yang demokratis dan bertanggung jawab"

Tujuan dari pendidikan karakter di sekolah adalah untuk meningkatkan mutu dan hasil pendidikan yang akan mengarah kepada pencapaian pembentukan karakter anak didik yang seimbang dengan standar kompetensi kelulusan. Dan seperti yang sudah disebutkan diatas bahwa tanggung jawab pembentukan karakter anak didik buka di msekolah saja, tapi harus berperan aktif dan bekerja sama dengan berbagai pihak tri pusat pendidikan terutama sekali adalah lingkungan keluarga. Karena anak didik hanya mengikuti pendidikan 7 jam perhari di sekolah, selebihnya ia berada di lingkungan keluarga dan masyarakat.

Di sekolah dasar ada dua mata pelajaran yang orientasinya untuk membentuk karakter anak didik yaitu ; mata pelajaran Pendidikan Agama Islam dan Pendidikan Kewarganegaraan. Dua mata pelajaran tersebut adalah solusi untuk pembinaan prilaku, akhlak, sikap, moral, dan karakter anak didik. Walaupun kedua mata pelajaran tersebut hanya mampu membekali anak didik tentang nilai-nilai melalui substansi mata pelajaran. Artinya kedua mata pelajaran tersebut belum bisa menggiring anak didik untuk memiliki karakter yang bisa berprilaku sesuai dengan substansi dari tujuan pembelajaran kedua mata pelajaran tersebut. Sejalan dengan hal tersebut Jalaludin (2012.11) mengatakan " PPKn dan pelajaranPendidikan Agama hanya melibatkan aspek kognitif(hafalan, tanpa ada apresiasi (emosi), dan praktik, sehingga tak heran kalau banyak manusia Indonesia yang hafal PancaSila atau ayat-ayat kitab sucinya, tetapi tidak tahu bagaimana membuang sampah yang benar, berlaku jujur, beretos kerja tinggi, dan menjalin hubungan harmonis dengan sesama."

Kalau kita merujuk kepada pendapat diatas, pembentukan karakter anak didik sangat perlu diintegrasikan kepada setiap mata pelajaran, dengan demikian terciptalah suatu program pembelajaran holistik untuk membentuk generasi yang cerdas, unggul dan berkarakter. Sesuai dengan kebijakan kurikulum 2013 yang orientasinya pada pembelajaran tematik khususnya di Sekolah Dasar terlaksana dengan baik. 


\section{Nilai-Nilai Pendidikan Karakter}

Dalam buku pengembangan Pendidikan Budaya dan Karakter Bangsa yang Kemendiknas melalui Badan Penelitian dan Pengembangan Pusat Kurikulum (kementerian Pendidikan Nasional, 2010) menybutkan ada delapan belas nilai karakter :" religius, yakni ketaatan dalam memahami dan melaksanakan ajaran ataupun sikap toleran terhadap agama lain, serta hidup rukun dan berdampingan. Jujur, yakni sikap dan perilaku yang mencerminkan kesatuan antara pengetahuan, perkataan, dan perbuatan. Toleransi, yakni sikap dan perilaku menghargai terhadap hal- hal perbedaan yang ada pada dirinya. Disiplin, yakni kebiasaan dan tindakan yang berkonsisten terhadap segala bentuk peraturan atau tata tertib yang berlaku. Kerja keras, yakni upaya secara sungguh-sungguh dalam menyelesaikan berbagai tugas, permasalahan, pekerjaan, dan lain-lain dengan sebaikbaiknya. Kreatif, yakni sikap dan perilaku selalu menemukan cara-cara baru, bahkan hasil-hasil baru yang lebih baik dari sebelumnya. Mandiri, yakni sikap dan perilaku yang tidak tergantung pada orang lain dalam menyelesaikan berbagai tugas maupun persoalan.

Demokratis, yakni sikap dan cara berpikir yang mencerminkan persamaan hak dan kewajiban secara adil dan merata antara dirinya dengan orang lain. Rasa ingin tahu, yakni sikap dan perilaku keingintahuan terhadap segala hal yang dilihat, didengar, dan dipelajari secara lebih mendalam. Semangat kebangsaan atau nasionalisme, yakni sikap dan tindakan yang menempatkan kepentingan bangsa dan negara di atas kepentingan pribadi atau golongan. Cinta tanah air, yakni sikap dan perilaku yang mencerminkan rasa bangga dan setia yang tinggi terhadap bahasa, budaya, ekonomi dan politik. Menghargai prestasi, yakni sikap terbuka terhadap prestasi orang lain dan mengakui kekurangan diri. Komunikatif, senang bersahabat atau proaktif, yakni sikap dan tindakan terbuka terhadap orang lain melalui komunikasi yang santun sehingga tercipta kerja sama secara kolaboratif dengan baik. Cinta damai, yakni sikap dan perilaku yang mencerminkan suasana damai, aman, tenang dan nyaman atas kehadiran dirinya dalam komunitas atau masyarakat tertentu. Gemar membaca, yakni kebiasaan untuk menyediakan waktu secara khusus guna membaca berbagai informasi. Peduli lingkungan, yakni sikap dan tindakan yang selalu berupaya menjaga dan melestarikan lingkungan sekitar. Peduli sosial, yakni sikap dan perbuatan yang mencerminkan kepedulian terhadap orang lain maupun masyarakat yang membutuhkannya. Tanggung jawab, yakni sikap dan perilaku seseorang dalam melaksanakan tugas dan kewajibannya, baik yang berkaitan dengan diri.

Sekolah sebagai sebuah lembaga pendidikan merupakan salah satu lembaga yang bertanggung jawab terhadap pembentukan karakter siswa. Peran dan kontribusi guru merupakan hal yang dominan. Guru mengembangkan nilai-nilai pendidikan karakter kepada siswa. Karakter yang telah ditanamankan lambat laun akan menjadi kebiasaan dan diimplementasikan dalam kehidupan sehari-hari. Nilai-nilai pendidikan karakter yang dapat diimplementasikan dalam kehidupan sehari-hari salah satunya yaitu adanya rasa empati terhadap segala seuatu yang ada disekitarnya.

Ni Putu Suwardani menulis dalam bukunya Quo Vadis Pendidikan Karakter: Dalam Merajut Harapan Bangsa yang Bermartabat "Pentingnya pendidikan karakter untuk membangun peradaban bangsa. Dalam hal ini peran Lembaga Pendidikan harus proaktif, kreatif dan inovatif dalam merancang proses pembelajaran yang benar-benar mampu memberikan kotribusi bagi pembentukan karakter. Dengan demikian proses pendidikan karakter dirancang secara menyeluruh dan kontekstual sehingga mampu membangun pemikiran yang dialogis-kritis dalam membentuk manusia yang berkarakter. Pendidikan itu harus menjadi " the power in building character" 
Selanjutnya masa perkembangan anak didik merupakan proses kehidupan yang ditempuh melalui fase-fase dalam rentang kehidupan, mulai dari masa dalam kandungan, masa bayi, masa kana-kanak, masa remaja, dewasa dan tua. Perkembangan dan perubahannya bisa juga kita lihat melalui perubahan pisik dan prilaku. Karakteristik anak didik di sekolah dasar diantaranya, ia suka bermain, suka bergerak, suka bekerja dalam kelompok dan suka meniru secara langsung terhadap apa yang ia lihat. (Abdul Alim, 2009:82).

\section{Pembentukan Karakter Melalui Pembelajaran Tematik.}

Pembelajaran Tematik diartikan sebagai pembelajaran yang menggunakan tema untuk mengaitkan beberapa mata pelajaran sehingga dapat memberikan pengalaman bermakna kepada siswa. Pembelajaran tematik lebih menekankan pada penerapan konsep belajar sambil melakukan sesuatu (learning by doing) (Daryanto \& Darmiatun 2014: 3). Hal ini sejalan dengan pendapat Prastowo (2015: 13-14) yang mengatakan bahwa pembelajaran berbasis tematik integratif yang diterapkan pada tingkatan pendidikan dasar menyuguhkan proses belajar berdasarkan tema. Tema tersebut kemudian dikombinasikan dengan mata pelajaran lainnya. Jadi satu tema terdiri dari beberapa mata pelajaran.

Dalam pemnbelajaran terpadu (tematik) anak didik menjadi aktif menggali dan menemukan konsep serta prinsip keilmuan secara menyeluruh, bermakna dan autentik baik secara individual dan kelompok. Karena pembelajaran tematik berorientasi pada praktik pembelajaran sesuai dengan perkembangan anak didik. Materinya dikemas dalam bentuk tematema berdasarkan muatan beberapa mata pelajaran yang dipadukan. Tematik diberikan dengan tujuan menyatukan konten kurikulum dalam unit-unit atau satuan-satuan yang utuh, sehingga membuat pembelajaran sarat akan nilai, bermakna dan mudah dipahami oleh anak didik.

Rusman 2015, dalam bukunya Pembelajaran Tematik Terpadu menjelaskan sebagai salah satu pendekatan pembelajran yang efektif, karena mampumewadahi dan menyentuh secara terpadu dimensi afeksi, fisik, dan akdemik anak didik dalam kelas. Lanjutnya " intinya pembelajaran tematik adalah anak didik memerlukan peluang-peluang tambahan untuk menggunakan talentanya, menyediakan waktu bersama yang lain untuk secara cepat mengkonseptualisasi dan mensintesis. Pembelajaran tematik sangat relevan untuk mengakomodasi perbedaan kualitatif lingkungan belajar, dan diharapkan mam menginspirasi anak didik untuk memperoleh pengalaman belajar. Pembelajaran tematik sifatnya memandu anak didik mencapai kemampuan berpikir tingkat tinggi atau ketrampilan berpikir dengan mengoptimasi kecerdasan ganda, sebuah proses inovatif bagi pengembangan dimensi sikap, ketrampilan, dan pengetahuan yang dituntut dalam sebuah kurikulum baik KTSP dan Kurikulum 2013.

Dengan model pembelajaran tematik menjadi sebuah solusi atas permasalahan pembentukan karakter anak didik selama ini. Nilai - nilai karakter terintegrasi dengan mata pelajaran lainnya dapat membantu persoalan-persoalan yang selama ini terhadap pembentukan karak ter anak didik. Ada dua mata pelajaran sebagai pijakan pertama yakni Pendidikan Agama dan PPKn, kedua mata pelajaran ini diintegrasikan dengan mata pelajaran sains.

Salah satunya pengintegrasian pata pelajaran Pendidikan Agama Islam dengan Sains Sunhaji(2016 : 17 dalam Pembelajaran Tematik- Integratif menyebutkan “ Agama Islam memerintahkan kepada penganutnya untuk banyak berfikir, dengan berfikir manusia dapat mengetahui kekuasaan Allah melalui ayat-ayat-Nya, materi pelajaran Sains adalah mata pelajaran yang banyak menjelaskan tentang kejadian alam dan kelestariannya, dan tolak ukur Pendidikan Agama Islam adalah keimanan dan takwaan anak didik. Proses munculnya keimana dan ketaqwaan adalah salah satunya diawali dengan bertafakkur dan tadhabur tentang alam, bahwa ala mini adalah ciptaan Sang Khalik. Dari keyakinan maka muncullah keimanan yang 
salah satunya diawali dengan tafakkur dan tadhabur tentang alam tadi, dari keyakinan maka muncullah prilaku keimanan".

Untuk melihat tingkat ketaqwaan dan keimanan anak didik selalu berpilaku baik dan mempunyai karakter yang sesuai dengan sumber agama yang dianut oleh anak didik. Dukstra \& rene Veenstra, 2001 : 183 ) menjelaskan bahwa pendidikan harus mempunyai kontribusi terhadap pembentukan karakter, social dan budaya. Kerena itu pendidikan khususnya pembelajaran tidak hanya menciptakan aspek kognitif semata, tetapi yang lebih penting adalah afektif. Pendidikan yang hanya menciptakan kognitif hanya akan menjadikan manusia yang tidak seutuhnya.

\section{a. Konsep Pembelajaran Tematik}

Proses pembelajaran di sekolah dasar pada umumnya guru menggunakan metode ceramah, tanya jawab dari pada menggunakan metode-metode yang lain. Akhirnya pelaksanaan proses pembelajaran hanya terpusat pada guru dan buku teks tanpa adanya inovasi - inovasi yang diterapkan dalam pembelajaran. Dengan hadirnya konsep pembelajaran tematik akan merobah paradigma bahwa guru sekolah dasar (guru kelas) hanya menggunakan metode ceramah dan tanya jawab di kelasnya. Akan tetapi sekarang para guru sekolah dasar (guru kelas) dalam proses pembelajaran semuanya sudah menerapkan model pembelajaran tematik atau terpadu.

Dalam buku Pembelajaran Tematik di SD disebutkan bahwa "Pembelajaran tematik (terpadu) di sekolah dasar di kembangkan dengan landasan teori dan filsafat diantaranya; teori psikologi gestalt, teori perkembangan kognitif, teori konstruktivisme dan filsafat progresivisme. Dan menurut teori piaget bahwa kemampuan berpikir anak sekolash dasar berada pada tahap berpikir prasional kongkrit. Anak didik memandang dunia dari secara objektif bergeser dari satu aspek situasi ke aspek lain secara reflektif, dan memandang unsurunsur secara srentak, mulai membentuk dan mempergunakan keterhubungan aturan-aturan, prinsip ilmiah sederhana, dan menggunakan hubungan sebab akibat.

Dari pendapat diatas, maka anak usia sekolah dasar cenderung memiliki gaya belajar dengan ciri-ciri sebagai berikut; a) kongkrit artinya anak usia sekolah dasar belajar melalui apa yang ia lihat, dengar, dibaui (terlena dengan sesuatu yang ia lihat), diraba, dan otak-atik. b) integratif / holistik artinya anak usia sekolah dasar memandang sesuatu yang di pelajarinya sebagai suatu keutuhan ia belum mampu memilah antara konsep ilmu yang satu dengan ilmu yang lain, dan cara berpikirnya deduktif. c) hierarkis atinya anak usia sekolah dasar memandang belajar yang berkembang secara bertahap dari hal yang sederhana ke hal yang komleks.

\section{b. Model Pembelajaran Tematik/Terpadu}

Menurut Yacobs yang dikutip oleh Feri Tirtoni dalam buku Pembelajaran Temamtik di Sekolah Dasar bila ditinjau dari sifat materi dan cara memadukannya ia menyebutkan ada lima model pembelajaran tematik / terpadu yaitu; 1) indicipliner based model ( model berbasis pembelajaran terpisah, 2) parallel model (model parallel), 3) multi disciplinary model (model keterkaitan antar mata pelajaran), 4) inter disciplinary (model interdisipliner), 5) integrated model (model terpadu). Sedangkan menurut Fogarty menyebutkan ada sepuluh model pembelajaran tematik/terpadu bila ditinjau dari sifat materi, cara memadukan konsep, ketrampilan, dan unit tamatiknya yaitu; 1) connected model (model hubungan/ model terkait, 2) webbed model (model jarring laba-laba/model terjala),3) integrated model (model terpadu), 4) fragmented model (model terpisah), 5) nested model (model gugusan), 6) sequenced model 
(model urutan). 7) shared model (model gabung bagian) 8) threaded model (model rajutan), 9) immersed model (model celup), 10) networked model (model jaringan).

\section{c. Karakteristik Pembelajaran Tematik}

Setiap model pembelajaran tentunya ada karakteristik masing-masing, maka karakteristik pembelajaran tematik menurut tim puskur dalam buku pembelajaran Tematik di SD (2009.14) menyebutkan ; a) pembelajaran terpusat pada anak didik, b) memberikan pengalaman langsung pada anak didik, c) pemisahan mapel tidak kelihatan antar mapel menyatu, d) menyajikan berbagai konsep dala suatu proses pembelajaran sehingga bermakna, e) hasil pembelajaran dapat berkembang sesuai dengan minat dan kebutuhan anak.

Menurut Feri Tirtoni ada beberapa point tentang karakteristik pembelajaran tematik dalam bukunya Pembelajaran Terpadu di SD (2018: 191) menyebutkan bahwa; 1) dalam pembelajaran terpadu siswa dituntut untuk lebih aktif dan mencari tahu pengetahuan sendiri sedangkan pendidik hanya bertugas untuk mengarahkan, 2) melibatkan siswa secara langsung dalam proses pembelajaran. Siswa mengalami proses pembelajaran secara nyata atau faktual, 3) pembelajaran terpadu memusatkan perhatian pada pengamatan atau observasi suatu peristiwa dari mata pelajaran satu dengan mata pelajaran yang saling berhubungan. Pemisah antara bidang studi satu dengan lainnya tidak begitu menonjol sehingga siswa akan lebih mudah untuk memahami suatu peristiwa pembelajaran dari segala sisi. Pembelajaran difokuskan pada tema yang berkaitan dengan kehidupan, 4)pembelajaran terpadu mengkaji suatu peristiwa dari berbagai macam aspek yang membentuk semacam konsep yang dimiliki oleh peserta didik. Keterkaitan antara konsep satu dengan lainnya akan menambah kebermaknaan suatu pembelajaran 5) dengan konsep yang dipelajari secara utuh diharapkan peserta didik mampu menerapkan hasil belajarnya untuk memecahkan masalah-masalah faktual yang sedang dihadapi, 6) anak didik sangat bersemangat dalam proses pembelajaran terpadu, hal ini dikarenakan pembelajaran yang dilakukan tidak membosankan dan menarik untuk peserta didik, karena pembelajaran ini saling mengkaitkan atau menghubungkan dari beberapa mata pelajaran yang nantinya akan dibentuk menjadi suatu tema, anak didik diberi kesempatan untuk memaksimalkanpotensi yang dimiliki oleh peserta didik yang sesuai dengan minat yang dimiki dan kebutuhannya.

\section{d. Pengintegrasian dalam Semua Mata Pelajaran}

Menurut Zubaedi (2011) "Pendidikan karakter pada dasarnya melekat pada setiap mata pelajaran, karena setiap mata pelajaran pada dasarnya memiliki nilai-nilai karakter yang harus dilalui dan dicapai oleh anak didik. Pada umumnya pendidikan karakter melekat dengan sendirinya di setiap mata pelajaran, sebab setiap mata palajaran mempunyai karakternya sendiri, maka setiap anak didik harus dilaluinya dan harus mencapai tujuannya. Hanya saja ada guru yang tidak menyadari bahwa ada nilai-nilai karakter yang dapat membentuk karakter dari anak didiknya. Dengan demikian perlu ditumbuh kembangkan kesadaran bagi setiap guru untuk selalu melaksanakan dan melakukan pengintegrasian pendidikan karakter di setiap mata pelajaran. Guru bisa menyelipkan Pendidikan karakter kepada anak didik, nantinya tanpa disadari anak didik akan mempengaruhi prilakunya dan dapat diterapkan dalam kehidupannya.

Lebih lanjut Feri Tirtoni menyebutkan beberapa point tentang karakteristik pembelajaran tematik dalam bukunya Pembelajaran Terpadu di SD (2018: 37 ) Untuk pengintegrasikan nilai-nilai karakter dalam mata pelajaran dapat dilakukan dengan cara antara lain: a) mengungkapkan nilai - nilai karakter yang terkandung dalam setiap mata pelajaran, 2) peintergrasian nilai-nilai karakter langsung kedalam mata pelajaran, 3) menggunakan perumpamaan dan perbandingan dengan kejadian yang serupa dalam kehidupan anak didik, 4) 
mengubah dari yang negatif ke positif, 5) mengungkapkan nilai-nilai melalui diskusi dan brainstorming, 6) menggunakan cerita untuk memunculkan nilai-nilai karakter, 7) menceritakan kisah hidup para tukoh yang peran dalam berbagai hal, menggunaka musik dan lagu dalam rang mengintegrasukan nilai-nilai karakter, 8) menggunakan drama dan film yang mengisahkan tentang nilai- nilai karakter, 9) dan menggunakan berbagai macam kegiatan amal, sosial, dan lainnya untuk memunculkan nilai-nilai kemanusiaan.

Seperti sudah dijelaskan sebelumnya bahwa dalam pengintegrasian pendidikan karakter kedalam semua mata pelajaran adalah peran dari mata pelajaran Pendidikan Agama dan Pendidikan Kewarganegaraan sangat dominan dalam membangaun karakter dan moral anak didik, disamping itu perlu juga mendapat dukungan dari mata pelajaran yang lain seperti Penjaskes, IPS, IPA (sains), dan matematika dan lainnya.

\section{Pendidikan Agama.}

Mata pelajaran pendidikan agama wajib diikuti setiap sekolah oleh semua anak didik, sesui yang ditulis oleh Feri Tirtoni dalam bukunya Pembelajaran Terpadu di SD (2018: 38) bila ditinjau dari segi muatan pendidikannya, PAI merupakan mata pelajaran pokok yang menjadi satu komponen yang tidak dapat dipisahkan dengan mata pelajaran lain yang bertujuan untuk pengembangan moral dan kepribadian peserta didik. Semua mata pelajaran yang memiliki tujuan tersebut harus seiring dan sejalan dengan tujuan yang ingin dicapai oleh mata pelajaran PAI. Diberikannya mata pelajaran PAI bertujuan untuk terbentuknya peserta didik yang beriman pendidikan bertakwa kepada Allah SWT, berbudi pekerti yang luhur (berakhlak yang mulia), dan memiliki pengetahuan yang cukup tentang Islam, terutama sumber ajaran dan sendi-sendi Islam lainnya, sehingga dapat dijadikan bekal untuk mempelajari berbagai bidang ilmu atau mata pelajaran tanpa harus terbawa oleh pengaruh-pengaruh negatif yang mungkin ditimbulkan oleh ilmu dan mata pelajaran tersebut. PAI menjadi mata pelajaran yang tidak hanya mengantarkan peserta didik dapat menguasai berbagai kajian keislaman, tetapi PAI lebih menekankan bagaimana peserta didik mampu menguasai kajian keislaman tersebut sekaligus dapat mengamalkannya dalam kehidupan sehari-hari ditengah-tengah masyarakat.

Dengan demikian mata pelajaran pendidikan agama adalah mata pelajaran yang utama yang selalu bisa terintegrasi dengan mata pelajaran lainnya. Keberadaan mata pelajaran Pendidikan agama dapat membangun karakter, moral, akhlak anak didik. Seorang guru pendidikan agama disamping ia melaksanakan tugas keagamaan, ia juga dapat melaksanakan tugas pendidikan dan sekaligus dapat membentuk karakter, kapribadian anak didik sesui dengan tujuan dari pembelajaran pendidikan agama.

\section{Mata Pelajaran Pendidikan Kewarganegaraan (PKn)}

Seperti sudah penulis jelaskan bahwa peran dari mata pelajaran pendidikan agama dalam membentuk karakter anak didik lebih optimal jika mendapat dukungan dari mata pelajaran pendidikan kewarganegaraan (PKn). Menurut Malik Fajar dikutip oleh Feri Tirtoni dalam bukunya Pembelajaran Terpadu di Sekolah Dasar bahwa, PKn memiliki peranan penting sebagai wahana untuk mengembangkan kemampuan, watak dan karakter warga negara yang demokratis dan bertanggung jawab. Dalam pencapaian ini, PKn perlu segera dikembangkan dan dituangkan dalam bentuk standar nasional, standar materi serta model - model pembelajaran yang efektif, dengan memperhatikan empat hal. Pertama, mengembangkan kemampuan dasar terkait dengan kemampuan intelektual, sosial (berpikir, bersikap, bertindak, serta berpartisipasi dalam hidup masyarakat). Substansi pendidikan (cita-cita, nilai, dan konsep demokrasi) dijadikan materi kurikulum PKn yang bersumber pada pilar- pilar 
demokrasi konstitusional Indonesia.Kedua, PKn perlu mengembangkan daya nalar (State of mind) peserta didik, pengembangan kecerdasan (Civic intelligence), tanggung jawab (Civic responbility), dan partisipasi (Civic participation) warga negara sebagai landasan pengembangan nilai dan perilaku demokrasi. Ketiga, PKn perlu mengembangkan pendekatan pembelajaranyang lebih inspiratif dan partisipatif dengan menekankan pada pelatihan penggunaan logika dan penalaran. Keempat, kelas PKn sebagai laboratorium demokrasi bukan sekedar membutuhkan pemahaman, sikap dan perilaku demokratis melalui mengajar demokrasi (Teaching democracy), tetapi memerlukan model pembelajaran yang secara langsung menerapkan cara hidup berdemokrasi (Doing democracy). ( Malik, 2004: 6-8).

Jadi mata pelajaran pendidikan kewarganegaraan tidak saja mengajarkan tentang bagaimana dalam bernegara dengan baik, akan tetapi mata pelajaran kewarganegaraan memiliki peran yang sangat penting dalam membentuk wahana sebagai pengetahuan. Mata pelajaran pendidikan kewarganegaraan juga mengajarkan anak didik untuk berkarakter dan memiliki moral dan dapat bersosialisasi dengan lingkungan sekitar. Selain itu mata pelajaran pkn memiliki peran yang sangat besar untuk membentuk siswa menjadi warga negara yang bisa mengemban semua permasalahan negara dan mencapai tujuan negaranya. Mata pelajaran Pendidikan kewarganegaraan juga banyak mengajarkan nilai-nilai pada anak didik, nilai-nilai kebaikan, kebersamaan, pengorbanan, menghargai orang lain dan persatuan ini jika di tanamkan dalam diri siswa bisa menjadi bekal yang sangat berharga dalam kehidupan pribadi maupun berbangsa dan bernegara.

Depdiknas (2003 : 2) bahwa, mata pelajaran pkn memiliki beberapa dimensi sebuah pengetahuan kewarganegaraan (civics knowledge) yang mencakup bidang politik, hukum dan moral. Didalam dimensi tersebut kita sebagai seorang guru harus menciptakan sebuah moral atau sikap kepada para peserta didik agar mereka nantinya dapat memiliki sikap kepribadian yang baik terhadap bangsa baik dari segi individu maupun kelompok. Hukum, kita juga sebagai seorang guru harus mengajarkan kepada para peserta didik tentang nilainilai hukum apa saja yang tidak boleh dilanggar. Baik itu dalam sekolah, bangsa maupun negara. Agar mereka nantinya dapat memiliki sikap yang patriotisme dan nasionalisme kepada bangsa. Dimensi ketrampilan Kewarganegaraan (civics skill) meliputi ketrampilan, partisipasi dalam kehidupan berbangsa dan bernegara. Dimensi nilai-nilai Kewarganegaraan (civics values) mencakup antara lain percaya diri, komitmen, penguasaan atas nilai religius, norma dan moral luhur, nilai keadilan, demokratis, toleransi, kebebasan individual, kebebasan berbicara, kebebasan pers, kebebasan berserikat dan berkumpul dan perlindungan terhadap minoritas.

\section{Mata Pelajaran Pendidikan Jasmani .}

Untuk pembentukan karakter anak didik bisa melalui pembelajaran pendidikan olah raga Menurut Park (1983) menyatakan bahwa peluang mengajarkan nilai - nilai etika dan moral yang mempengaruhi perilaku siswa dapat dikembangkan melalui olahraga dan permainan. Dalam konteks ini, peran guru pendidikan jasmani perlu ditekankan agar dapat mengatasi masalah - masalah etika dan mengembangkan perilaku yang bertanggung jawabsecara moral dalam olahraga. Berdasarkan paparan ini dapat dikatakan bahwa para pendidik sangat yakin salah satu tujuan pendidikan, khususnya pendidikan jasmani adalah menekankan hasil ranah afektif atau perkembangan karakter dalam kurikulumnya. (Dimyati, $2010: 88)$.

Berdasarkan pendapat diatas bahwa mata pelajaran pendidika jasmani mempunyai nilai etika dan moral yang mempengaruhi karakter anak didik ketika mempraktikkan suatu 
olah raga dalam bentuk permainan. Dalam melakukannya ia punya tanggung jawab secara moral sehingga dapat menumbuhkan kepercayaan diri. Disini peran gurunya selalu menekankan nilai etika melalui ranah afektif dengan tujuan untuk pembentukan karakter anak didiknya. Salah satu karakter yang dapat ditumbuhkan melalui materi pelajaran olahraga adalah rasa percaya diri (Self confident). Rasa percaya diri sangat penting dibangun pada diri peserta didik mengingat ia akan menjadi modal berharga bagi seorang anak dalam menjalani kompetensi dalam kehidupan.

\section{Mata Pelajaran Ilmu Pengetahuan Sosial.}

Feri Tirtoni (2018:43) menjelaskan pedidikan berkarakter juga diemban oleh mata pelajaran ilmu pengetahuan sosial (IPS). IPS mempunyai tugas mulia dan menjadi fondasi penting bagi pengembangan intelektual, emosional, kultural dan sosial peserta didik, yaitu mampu menumbuhkan cara berpikir, bersikap dan berperilaku yang bertanggung jawab selaku individual, warga masyarakat, warga negara, dan warga dunia. Selain itu IPS juga bertugas mengembangkan potensi peserta didik agar peka terhadap masalah sosial yang terjadi di masyarakat, memiliki sikap mental positif untuk perbaikan segala ketimpangan dan terampil megatasi setiap masalah yang terjadi sehari - hari baik yang menimpa sendiri maupun di masyarakat.

Ilmu Pengetahuan Sosial merupakan bagian dari kurikulum sekolah yang tanggung jawab utamanya adalah membantu peserta didik dalam mengembangkan pengetahuan, keterampilan, sikap, nilai yang diperlukan untuk berpartisipasi dalam kehidupan masyarakat baik ditingkat lokal, nasional maupun global. (Enok, 2010 : 872).

Berkaitan dengan hal tersebut Pembelajaran IPS memiliki sebuah karakter yang dapat membantu siswa untuk memperluas ilmu sosial dan menerapkan kehidupan bersosial di masyarakat. Terutama dalam segi interaksi sosial mereka terhadap orang lain. Dengan cara berinteraksi anak akan mengalami suatu hubungan timbal balik yang saling mempengaruhi. Ada aksi dan ada reaksi dari orang yang berinteraksi dengan kita. antara individu dengan individu, individu dengan kelompok, maupun kelompok dengan kelompok. Interaksi sosial dibedakan menjadi dua yaitu interaksi secara langsung dan interaksi sosial yang tidak secara langsung. Interaksi sosial secara langsung apabila tanpa melalui perantara. Misalnya Humaira dan Al- Farisi saling bercakap-cakap diantara satu dengan yang lain dengan secara langsung termasuk contoh interaksi sosial secara langsung. Sedangkan kalau Az-Zahra titip salam ke Firdaus lewat Fahmi dan Fahmi meneruskan kembali ke Firdaus, maka ini termasuk interaksi sosial yang secara tidak langsung. Pendapat Enok, IPS merupakan bagian dari kurikulum sekolah yang tanggung jawab utamanya adalah membantu peserta didik dalam mengembangkan pengetahuan, keterampilan, sikap, nilai yang diperlukan untuk berpartisipasi dalam kehidupan masyarakat baik ditingkat lokal, nasional maupun global. Maka dari itu pembelajaran IPS sangat dibutuhkan bagi para peserta didik untuk mengembangkan pengetahuan mereka, keterampilan, sikap dan nilai-nilai sosial mereka untuk berpartisipasi dalam kehidupan masyarakat.

Ilmu Pengetahuan Sosial adalah mata pelajaran disekolah yang didesain atas dasar fenomena, masalah dan realitas sosial dengan pendekatan interdisipliner yang melibatkan berbagai cabang ilmu - ilmu sosial dan humaniora seperti kewarganegaraan, sejarah, geografi, ekonomi, sosiologi, antropologi pendidikan. Oleh karena itu, IPS dapat dikatakan sebagai studi mengenai perpaduan antara ilmu - ilmu dalam rumpun ilmu sosial dan juga humaniora untuk melahirkan pelaku - pelaku sosial yang dapat berpartisipasi dalam memecahkan masalah - masalah. 
Secara umum kompetensi dan tujuan pembelajaran IPS adalah mengantarkan, membimbing dan mengembangkan potensi peserta didik agar menjadi warga negara yang baik, mengembangkan kemampuan berpikir kritis dengan penuh kearifan untuk dapat memahami, menyikapi dan ikut memecahkan masalah sosial, serta membangun komitmen terhadap nilai - nilai luhur dan budaya Indonesia.

\section{Mata Pelajaran Ilmu Pengetahuan Alam}

Usaha guru kelas dalam menanam nilai-nilai karakter kepada anak didik dapat dilakukan melalui mata pelajaran Ilmu Pengetahuan Alam (sains). Sebagimana di kutip oleh Feri Tirtoni (20018: 44) Menurut Sumaji dkk, sebagaimana dikutip oleh Sofyan Sauri, Ilmu Pengetahuan Alam (sains) mengandung banyak sekali nilai kehidupan. Nilai moral yang dapat dikembangkan dalam hal ini menyangkut nilai kejujuran, rasa ingin tahu, serta keterbukaan. Proses sains dalam hal ini merupakan proses mempelajari serta mengambil makna pada kehidupan dan dunia di sekeliling kita.

Ilmu Pengetahuan Alam itu membahas tentang alam, manusia bagian dari alam dengan demikian keduanya mempunyai hubungan yang sangat erat. Manusia dapat menunjukkan kuasa Allah terhadap alam dan segala isinya. Lanjut Feri Tirtoni (2018: 45) menjelaskan bahwa banyaknya nilai penting kehidupan yang dapat dipelajari dari sains, memberi konsekuensi kepada para pendidik untuk dapat mengembangkan sains sebagai salah satu media dalam membentuk pribadi siswa. Dalam hal ini, siswa dapat diajak menelaah serta mempelajari nilai-nilai dalam sains yang berguna dalam kehidupan bermasyarakat. Menyadari hal ini, maka keterampilan mengajarkan nilai-nilai kehidupan melalui pembelajaran sains merupakan salah satu kompetensi penting yang harus dikuasai oleh guru sains. Kompetensi ini dipandang penting sehingga harus diajarkan mulai dari calon guru dan dilatihkan kepada calon guru selama proses praktik pengalaman lapangan di sekolah.

Urgennya pendidikan karakter dalam pembelajaran ilmu pengetahuan alam akan memberikan konsekuensi kepada para guru kelas untuk dapat mengembangkannya sebagai salah satu cara dalam membentuk karakter dari anak didik. Artinya guru mengajak anak didik untuk mempelajari dan menelaah nilai-nilai yang terkandung dalam ilmu pengeahuan alam yang mermanfaat bagi alam sekitarnya. Dengan pembelajaran secara holistik bukan mengajarkan materinya saja, akan tetapi juga mengajarkan nilai-nilai moral, karakter dengan cara menjelaskan contoh-contoh atau perumpamaan dari bahan ajar.

\section{Mata Pelajaran Matematika}

Pendidikan matematika juga memiliki nilai karakter yaitu terdapat nilai logis, artinya karakter untuk selalu berfikir logis, karena semua materi pembelajarannya punya rumus rumus yang tidak bisa di rekayasa. Melalui pembelajaran matematika guru dapat menanamkan sifat jujur, artinya guru mengajarkan anak didik untuk tidak pernah salah dalam menghitung, jangan pernah terjadi salah hitung data. Dalam konsep menghitung jangan pernah salah, konsep untuk kehidupan anak didiknya masa yang akan datang kelak ia sudah dewasa dan sudah bekerja nilai karakter yang ditanamkan oleh gurunya jangan pernah salah itu akan berdampak kelak ia tidak akan pernah memark-up dan korupsi.

Matematika sekolah adalah matematika yang telah dipilah-pilah dan disesuaikan dengan tahap perkembangan intelektual siswa, serta digunakan sebagai salah satu sarana untuk mengembangkan kemampuan berpikir bagi para siswa. Ada sedikit perbedaan antara matematika sebagai ilmu dengan matematika sekolah. Perbedaan itu dalam bentuk penyajian, pola pikir, keterbatasan semesta, dan tingkat keabstrakan (Sumardyono, 1994: 43-44). 
Pembelajaran matematika di sekolah memiliki sebuah tahapan dalam perkembangan intelektual anak didik, dapat dijadikan sebagai sarana untuk mengembangkan kemampuan pola piker anak didik. Menurut Soedjadi yang dikutip oleh Feri Tirtoni (2018: 47) bahwa, mata pelajaran matematika memiliki sebuah objek yang dapat meningkatkan sebuah perkembangan kognitif siswa dengan melalui sebuah pengetahuan yang kongkrit kemudian menuju ke abstrak, tetapi mengingat kemampuan berpikir siswa SD yang masih dalam tahap operasional konkrit, maka untuk memahami konsep dan prinsip masih diperlukan pengalaman melalui obyek kongkrit. Selain itu mata pelajaran matematika sebagai ilmu yang deduktif aksiomatis, dimana dalil-dalil atau prinsip-prinsip harus dibuktikan secara deduktif. Tetapi mengingat kemampuan berpikir siswa SD, penerapan pola deduktif tidak dilakukan secara ketat. Struktur sajian matematika tidak harus menggunakan pola pikir deduktif semata, tetapi dapat juga digunakan pola pikir induktif.

\section{e. Langkah Pengintegrasian}

Sebagaimana di sebutkan oleh Feri Tirtoni (2018: 49) bahwa langkah-langkah pengintegrasian nilai-nilai karakter pada setiap mata pelajaran termasuk dilakukan antara lain: dengan mencantumkan nilai-nilai karakter tersebut dalam Silabus dan Rencana Program Pembelajaran (RPP). Pengembangan nilai-nilai tersebut dalam silabus ditempuh melalui cara-cara sebagai berikut: 1) mengkaji Standar Kompetensi (SK) dan Kompetensi Dasar (KD) untuk menentukan apakah kandungan nilai-nilai dan karakter yang secara tersirat atau tersurat dalam SK dan KD di atas sudah tercakup di dalamnya, 2) memperlihatkan keterkaitan antara $\mathrm{SK} / \mathrm{KD}$ dan nilai dan indikator untuk menetukan nilai yang akan dikembangkan, 3) mencantumkan nilai-nilai dan karakter ke dalam silabus, 4) mencantumkan nilai-nilai yang sudah tercantum dalam silabus ke RPP, 5) mengembangkan proses pembelajaran peserta didik aktif yang memungkinkan peserta didik memiliki kesempatan melakukan internalisasi nilai dan menunjukkannya dalam perilaku yang sesuai, 6) memberikan bantuan kepada peserta didik yang mengalami kesulitan untuk internalisasi nilai maupun untuk menunjukkannya dalam perilaku.

\section{KESIMPULAN}

Dalam proses pembelajaran guru memiliki peran yang sangat penting dalam mendidik anak didiknya agar memiliki karakter dan pribadi yang baik. Dalam menjalankan perannya, guru harus selalu memberikan contoh karakter yang baik kepada anak didiknya, baik dalam hal berbicra maupu sikap. Dengan adanya hal tersebut maka peran dari guru kelas dalam membentuk karakter anak didik untuk berkarakter dengan baik akan tercapai apabila gurunya memiliki karakter dan sikap yang baik pula. Karakter dan kepribadian itu sangat penting, lebih penting dan tinggi karakter dari kecerdasan dsn intelektual, karena keseimbangan sebuah kehidupan sangat tergantung kepada nilai karakter yang dimiliki. Maka sekolah merupakan lingkungan yang sangat penting ke dua dalam pembentukan karakter anak didik, disamping di lingkungan rumah.

Pembelajaran tematik memiliki kesamaan dengan pembelajaran biasa, yang membedakannya secara mendasar adalah bila dalam pembelajaran biasa, bahasan materi pelajaran disusun berdasarkan struktur isi yang ada pada mata pelajaran atau bidang studi. Sedangkan dalam pembelajaran tematik bahasan materi tidak berpola oleh susunan materi bahasan satu bidang studi tertentu, tapi bahasan difokuskan pada suatu topik tertentu dan bahasanya ditinjau dari berbagai sudut pandang mata pelajaran atau bidang studi yang ada, yang dipandang sesuai atau perlu untuk memperjelas topik yang akan dibahas. Secara singkat, dalam pembelajaran terpadu terjadi penyatuan pembahasan topik dari berbagai mata pelajaran, tidak tunggal. 


\section{DAFTAR PUSTAKA}

Depdiknas, Undang-Undang Republik Indonesia Nomor 14 Tahun 2005 tentang Guru dan Dosen, Jakarta: Biro Hukum dan Organisasi Sekjen Depdiknas, 2013.

Depdiknas, Kurikulum 2004 mata pelajaran Pendidikan Kewarganegaraan. Jakarta: Departemen Pendidikan Nasional, 2003

Depdiknas, PanduanPengembanganPembelajaran IPA Terpadu, Jakarta: Depdiknas. Dikti, 2006.

Dewantara, K. 2013. Karya Ki Hadjar Dewantara Bagian: Pertama. Yogyakarta: Majelis Luhur Persatuan Tamansiswa.

Dimyati, Peran Guru sebagai Model dalam Pembelajaran Karakter dan Kebajikan Moral Melalui Pendidikan Jasmani, dalam Cakrawala Pendidikan, Yogyakarta, UNY, Mei 2010, Th XXIX, Edisi Khusus Dies Natalis UNY, 2010.

Enok Maryani, Pengembangan Program Pembelajaran IPS Untuk Meningkatkan Kompetensi Keterampilan Sosial, Makalah dalam Proceedings of The 4th International Conference on Teacher Education: Join Conference UPI dan UPSI Bandung: 8-10 November 2010

Feri Tirtoni , M. Pd, Pembelajaran terpadu di SD, UMSIDA Press, 2018. Jalaludin, Membangun SDM Bangsa Melalui Pendidikan Karakter, Jurnal UPI: Penelitian Pendidikan, 2012.

Kemendiknas, Kementerian Pendidikan Nasional tentang Pengembangan Pendidikan Budaya dan karakter Bangsa. Jakarta: Kemendiknas, 2010.

Marzuki, Pendidikan Karakter Islam, Jakarta: Amzah, 2017.

Moh Roqib dan Nurfuadi, Kepribadian Guru Upaya Mengembangkan Kepribadian Guru yang Sehat di Masa Depan, Yogyakarta: Grafindo Litera Media, 2009.

Proseding Seminar Nasional PGSD, 27 April 2019/ ISBN-602-6258-II-3, Peran Pendidikan Dasar Dalam Menyiapkan Generasi Unggul di Era Revolusi Industri 4.0, diunduh 4 Juni 2021.

Ramayulis, Ilmu Pendidikan Islam, Jakarta: Kalam Media, 2008.

Rusman. Pembelajaran Tematik Terpadu, Raja Wali Pers, 2015

Sauri, Sofyan, Revitalisasi Pendidikan Sains dalam Pembentukan Karakter Anak Bangsa untuk Menghadapi Tantangan Global, Makalah dalam file.upi.edu. Di akses pada 21 Juni 2021

Sobry, Sutikno, Beberhasilan Belajar Mengajar, Jakarta: Rineke Cipta, 2002

Soedjadi, R. Kiat Pendidikan Matematika diIndonesia.Jakarta: Ditjen, 2000.

Sumadi Suryabrata, Metodologi Penelitian, Jakarta: Raja Wali Pers 1995.

Sumardyono, Karakteristik Matematika dan Implikasinya terhadap Pembelajaran. 2004

Sutrisno Hadi, Metodologi Research, Yogyakarta: fak. Psikologi UGM. 1990.

Tim Direktorat Pembinaan Sekolah Dasar, Panduan Pembinaan Pendidikan Karakter Melalui Pengembangan Budaya Sekolah Di Sekolah Dasar, Jakarta: Kemendikbud, 2013.

Tisno dan Ida,dkk, Pembelajaran Terpadu di SD. Jakarta: Universitas Terbuka, 2008.

Trianto. Model Pembelajaran terpadu dalam Teori dan Praktek. Jakarta: Prestasi Pustaka Publisher, 2007.

Trianto, Desain Pengembangan Pembelajaran Tematik. Jakarta. Kencana Pranada Media Group, 2011.

Wahyudi, Imam, Mengejar Profesionalisme Guru, Jakarta: Prestasi Pustaka Karya, 2012

Wibowo, Agus, Pendidikan Karakter, Strategi Membangun Karakter Bangsa Berperadaban, Yogyakarta: Pustaka Pelajar, 2012

Yenni Fitra Surya, Penggunaan Model Pembelajaran Pendidikan Karakter Abad 21 Pada Anak Usia Dini. Jurnal Obsesi, Vol. 1 No. 1 (2017), h. 55. 


\section{Yunus Abidin, Revitalisasi Penilaian Pembelajaran dalam Konteks Pendidikan} Multiliterasi Abad Ke-21, Bandung: PT. Refika Aditama, 2016.

Zubaedi, Desain Pendidikan Karakter Konsepsi dan Aplikasinya Dalam Lembaga Pendidikan (Jakarta: Prenadamedia Group, 2015), h. 19. 